\title{
A three-phase in-vitro system for studying Pseudomonas aeruginosa adhesion and biofilm formation upon hydrogel contact lenses
}

\author{
Claudia Rändler ${ }^{1}$, Rutger Matthes ${ }^{1 \dagger}$, Andrew J McBain ${ }^{2 \dagger}$, Bernd Giese $^{3}$, Martin Fraunholz ${ }^{3}$, Rabea Sietmann ${ }^{4}$,
} Thomas Kohlmann ${ }^{5}$, Nils-Olaf Hübner ${ }^{1}$, Axel Kramer ${ }^{1 *}$

\begin{abstract}
Background: Pseudomonas aeruginosa is commonly associated with contact lens (CL) -related eye infections, for which bacterial adhesion and biofilm formation upon hydrogel CLs is a specific risk factor. Whilst $P$. aeruginosa has been widely used as a model organism for initial biofilm formation on CLs, in-vitro models that closely reproduce in-vivo conditions have rarely been presented.

Results: In the current investigation, a novel in-vitro biofilm model for studying the adherence of $P$. aeruginosa to hydrogel CLs was established. Nutritional and interfacial conditions similar to those in the eye of a CL wearer were created through the involvement of a solid:liquid and a solid:air interface, shear forces and a complex artificial tear fluid. Bioburdens varied depending on the $\mathrm{CL}$ material and biofilm maturation occurred after $72 \mathrm{~h}$ incubation. Whilst a range of biofilm morphologies were visualised including dispersed and adherent bacterial cells, aggregates and colonies embedded in extracellular polymer substances (EPS), EPS fibres, mushroom-like formations, and crystalline structures, a compact and heterogeneous biofilm morphology predominated on all CL materials.

Conclusions: In order to better understand the process of biofilm formation on CLs and to test the efficacy of $\mathrm{CL}$ care solutions, representative in-vitro biofilm models are required. Here, we present a three-phase biofilm model that simulates the environment in the eye of a $\mathrm{CL}$ wearer and thus generates biofilms which resemble those commonly observed in-situ.
\end{abstract}

\section{Background}

The use of contact lenses (CLs) is a major risk factor for the development of microbial keratitis [1-3]. Whilst Gram-negative bacteria, particularly $P$. aeruginosa, are commonly associated with the condition, within the last four years, two notable outbreaks of CL-associated infectious keratitis have occurred, which were caused by the normally uncommon agents, Fusarium (2006 in Singapore, Hong Kong and the USA) and Acanthamoeba (2007 in USA). These infections were associated with the use of the CL care solutions "ReNu • with MoistureLoc" $^{\oplus "}$ and "Complete ${ }^{\odot}$ MoisturePlus ${ }^{\mathrm{Tw}}$, , respectively [4].

\footnotetext{
* Correspondence: kramer@uni-greifswald.de

† Contributed equally

'Department of Hygiene and Environmental Medicine, Ernst Moritz Arndt University Greifswald, Greifswald, Germany

Full list of author information is available at the end of the article
}

The ability of microorganisms to adhere to CL surfaces and to form biofilms plays an important role in the development of CL-related eye infections [5]. Bacterial adhesion and the associated infection risk are influenced by a combination of different factors which include: i. the composition of an individual's tear fluid (organic and inorganic substances) [6]; ii. environment (weather, temperature, air pollution) [7]; iii. CL composition (material, water content, ionic strength) [8]; iv. the nature and quantity of the microbial challenge (species, strain) [8]; v. wearer habits (such as swimming and sleeping during CL wear) [9]; and vi. CL hygiene (CL care solution and CL handling) [7,10-12]. Furthermore, biofilms are a risk factor for concomitant infections with other microorganisms, including Acanthamoeba, which can co-exist synergistically with $P$. aeruginosa in biofilms, resulting in an increased risk of Acanthamoeba keratitis [13]. Biofilm formation on CLs is therefore a

c 2010 Rändler et al; licensee BioMed Central Ltd. This is an Open Access article distributed under the terms of the Creative Commons Attribution License (http://creativecommons.org/licenses/by/2.0), which permits unrestricted use, distribution, and reproduction in any medium, provided the original work is properly cited. 
complex process which may differ markedly between individuals.

One of the most common organisms associated with bacterial adhesion to CLs and with CL-related eye infections is $P$. aeruginosa $[10,14]$. $P$. aeruginosa is commonly isolated from soil and aquatic environments, is well adapted to survive in water and aqueous eye-products [14], and, through a number of physiological adaptations is generally recalcitrant and can often survive exposure to enzymatic CL care products [15]. As a versatile opportunistic pathogen, it is frequently associated with corneal ulcers. $P$. aeruginosa is accordingly a commonly studied model organism for the in-vitro investigation of biofilm formation on CLs [8,13,16-31]. Most previous in-vitro studies of biofilm formation on CLs have focused on initial bacterial adherence; only a limited number of reports have described models designed to maximise validity in investigations of the anti-biofilm efficacy of CL solutions [32,33]. With respect to simulating the milieu of the human eye, studies which have utilised saline omit important factors which may promote biofilm development [13,23-29]. Hence, there is a need for in-vitro biofilm models that more closely mimic the conditions in the eye of a CL wearer. Such models may contribute to understanding the complex process of in-vivo biofilm formation and facilitate the evaluation of the anti-biofilm efficacy of CL care solutions. Data thus generated can be used to calculate and minimise the risk of microbe-associated and CL-related eye diseases. The aim of the current study therefore, was to develop a realistic in-vitro biofilm model for the bacterial adhesion of $P$. aeruginosa to hydrogel CLs under conditions which resemble the environment in the eye of a CL wearer. Bacterial adherence was evaluated over time by counting colony forming units (CFUs). The morphology and composition of the biofilms were analysed by confocal laser scanning and scanning electron microscopy.

\section{Methods}

\section{Contact lenses}

Four different hydrogel CLs were studied corresponding to the FDA Groups (FDA Group 1: non-ionic, low water $\left(<50 \% \mathrm{H}_{2} \mathrm{O}\right)$; FDA Group 2: non-ionic, high water $(>50 \%$ $\mathrm{H}_{2} \mathrm{O}$ ); and FDA Group 4: ionic, high water $(>50 \%$ $\left.\mathrm{H}_{2} \mathrm{O}\right)$ ). The CLs examined in this study are described in detail in Table 1. CLs of the minor FDA Group 3 (ionic/low water) were not included in this study, because the physicochemical properties of these CLs are similar to that of the FDA Group 4. Instead, two widely used silicone hydrogel CLs (FDA Group 1) with different characteristics were selected. In all cases, unused CLs were removed from the original package and washed with sterile isotonic saline prior to use in the biofilm model. For the sake of consistency, all CLs exhibited a power of -3.00 dioptre.

\section{Artificial tear fluid}

A mixture of human blood serum $(20 \% \mathrm{v} / \mathrm{v})$ and lysozyme ( 2 g/L, Sigma Aldrich, Steinheim, Germany) diluted in an ocular irrigation solution $\mathrm{BSS}^{\circ}$ (balanced salt solution, Delta Select GmbH, Dreieck, Germany) was used as artificial tear fluid. Human blood serum was obtained from healthy blood donors in the Department of Transfusion Medicine of the University of Greifswald (Germany). Donors gave informed consent to provide an additional blood sample of $8 \mathrm{~mL}$ whole blood for research purposes. The serum samples were collected in $50 \mathrm{~mL}$ tubes and stored at $-20^{\circ} \mathrm{C}$.

\section{Test bacterium and growth conditions}

The mucoid environmental $P$. aeruginosa strain SG81, previously isolated from a biofilm in a technical water system, was kindly supplied by Prof. Dr. Hans-Curt Flemming (Biofilm Center, Duisburg, Germany) and stored at $-20^{\circ} \mathrm{C}$. The test bacterium was grown on Columbia blood agar (BD, Heidelberg, Germany) for $24 \mathrm{~h}$ at $37^{\circ} \mathrm{C}$. Thereafter, a single colony was inoculated onto a trypticase soy agar plate (TSA, Oxoid, Wesel, Germany) and was incubated for $24 \mathrm{~h}$ at $37^{\circ} \mathrm{C}$. In order to prepare a washed cell inoculum for the biofilm model, the colonies were harvested from the agar plate by scraping with a Spatula Drigalski and suspended in $10 \mathrm{~mL}$ PBS (pH 7.2; 0.1418 $\mathrm{mol} / \mathrm{L} \mathrm{NaCl}, 0.0030 \mathrm{~mol} / \mathrm{L} \mathrm{KCl}, 0.0067 \mathrm{~mol} / \mathrm{L} \mathrm{Na}_{2} \mathrm{HPO}_{4}$ and $0.0016 \mathrm{~mol} / \mathrm{L} \mathrm{KH}_{2} \mathrm{PO}_{4}$ ). Harvested bacteria were then washed twice by centrifugation for $15 \mathrm{~min}$ at $3000 \times \mathrm{g}$, the resuspension in $5 \mathrm{~mL}$ ocular irrigation solution $\mathrm{BSS}^{\circ}$ to yield a final concentration of $1 \times 10^{10} \mathrm{CFU} / \mathrm{mL}$ which was verified by colony-counting as outlined below.

\section{Bacterial adhesion studies with the three-phase biofilm model}

The biofilm model was housed and replicated within in a 24-well microtiter plate (Sarstedt, Nümbrecht, Germany). Convex polycarbonate coupons (PCs, in-house production) were used as the contact surface for the CLs and were placed in the wells (Figure 1). The bacterial suspension, consisting of the artificial tear fluid and the bacterial cells in a ratio of 5:1 was adjusted to a final concentration of approximately $1.0 \times 10^{9} \mathrm{CFU} / \mathrm{mL}$. CLs were placed convex side up on the top of the PCs in the wells of the microtiter plate, each well containing $1 \mathrm{~mL}$ of the bacterial suspension as illustrated in Figure 1. The CLs were incubated with an agitation of $240 \mathrm{rpm}$ at room temperature.

\section{Determination of the biofilm growth on contact lenses}

The CLs were incubated in the biofilm model for 2, 4, 8, 12, 24, 36, 48 and 72 h. After incubation, CLs were 
Table 1 Properties of hydrogel contact lenses used in this study

\begin{tabular}{|c|c|c|c|c|}
\hline Proprietary name & ACUVUE 2 & PROCLEAR & BIOFINITY & AIROPTIX \\
\hline $\begin{array}{l}\text { United States Adopted } \\
\text { Name (USAN) }\end{array}$ & Etafilcon A & Omafilcon A & Comfilcon A & Lotrafilcon B \\
\hline Manufacturer & Johnson \& Johnson & Cooper Vision & Cooper Vision & CIBA Vision \\
\hline Water content (\%) & 58 & 62 & 48 & 33 \\
\hline Ionic charge & Ionic & Non-ionic & Non-ionic & Non-ionic \\
\hline $\begin{array}{l}\text { Oxygen permeability } \\
(\mathrm{Dk})\end{array}$ & 22 & 27 & 128 & 110 \\
\hline $\begin{array}{l}\text { Centre thickness }(\mathrm{mm}) \\
-3.00 \mathrm{D}\end{array}$ & 0.084 & 0.065 & 0.08 & 0.08 \\
\hline $\begin{array}{l}\text { Oxygen transmissibility } \\
(\mathrm{Dk} / \mathrm{t}) \text { at } 35^{\circ} \mathrm{C}\end{array}$ & 33.3 & 42 & 160 & 138 \\
\hline Basis curve (mm) & 8.7 & 8.6 & 8.6 & 8.6 \\
\hline Diameter (mm) & 14.0 & 14.2 & 14.0 & 14.2 \\
\hline Surface treatment & None & None & None & $\begin{array}{l}\text { 25-nm-thick plasma coating with } \\
\text { high refractive index }\end{array}$ \\
\hline FDA Group & 4 (Conventional hydrogel) & $\begin{array}{l}2 \text { (Conventional } \\
\text { hydrogel) }\end{array}$ & 1 (Silicone hydrogel) $^{\alpha}$ & 1 (Silicone hydrogel) $^{\beta}$ \\
\hline $\begin{array}{l}\text { Replacement and } \\
\text { wearing schedule* }\end{array}$ & $\begin{array}{c}\text { Every } 2 \text { weeks (daily wear) } O R \text { six } \\
\text { nights extended wear }\end{array}$ & $\begin{array}{l}\text { Every } 4 \text { weeks } \\
\text { (daily wear) }\end{array}$ & $\begin{array}{l}\text { Every } 4 \text { weeks (daily, } \\
\text { continuous OR flexible wear) }\end{array}$ & $\begin{array}{c}\text { Every } 4 \text { weeks (daily wear) } O R \text { up to } \\
\text { six nights extended wear }\end{array}$ \\
\hline Principal monomers & HEMA, MA & HEMA, PC & $\begin{array}{c}\text { FM0411M, HOB, IBM, M3U, } \\
\text { NVP, TAIC, VMA }\end{array}$ & DMA, TRIS, siloxane monomer \\
\hline
\end{tabular}

HEMA (poly-2-hydroxyethyl methacrylate); MA (methacrylic acid); PC (phoshoryl choline); DMA (N,N-dimethylacryl amide); TRIS (trimethylsiloxy silane); DMA, N,Ndimethylacrylamide; FM0411M ( $\alpha$-methacryloyloxyethyl iminocarboxyethyloxypropyl-poly(dimethylsiloxy)-butyldimethylsilane); HOB (2-hydroxybutyl methacrylate); IBM (isobornyl methacrylate); M3U $\alpha \omega$-bis(methacryloyloxyethyl iminocarboxy ethyloxypropyl)-poly(dimethylsiloxane)-poly(trifluoropropylmethylsiloxane)-poly( $\omega$ methoxy- poly(ethyleneglycol)propylmethylsiloxane); NVP (N-vinyl pyrrolidone); TAIC (1,3,5-triallyl-1,3,5-triazine-2,4,6(1H,3H,5H)-trione); VMA (N-Vinyl-Nmethylacetamide)

${ }^{\alpha}$ third silicone generation

$\beta$ first silicone generation

*It is recommended that the CL wearer first be evaluated on a daily wear schedule. If successful, then a gradual introduction of extended wear can be followed as determined by the prescribing Eye Care Practitioner.

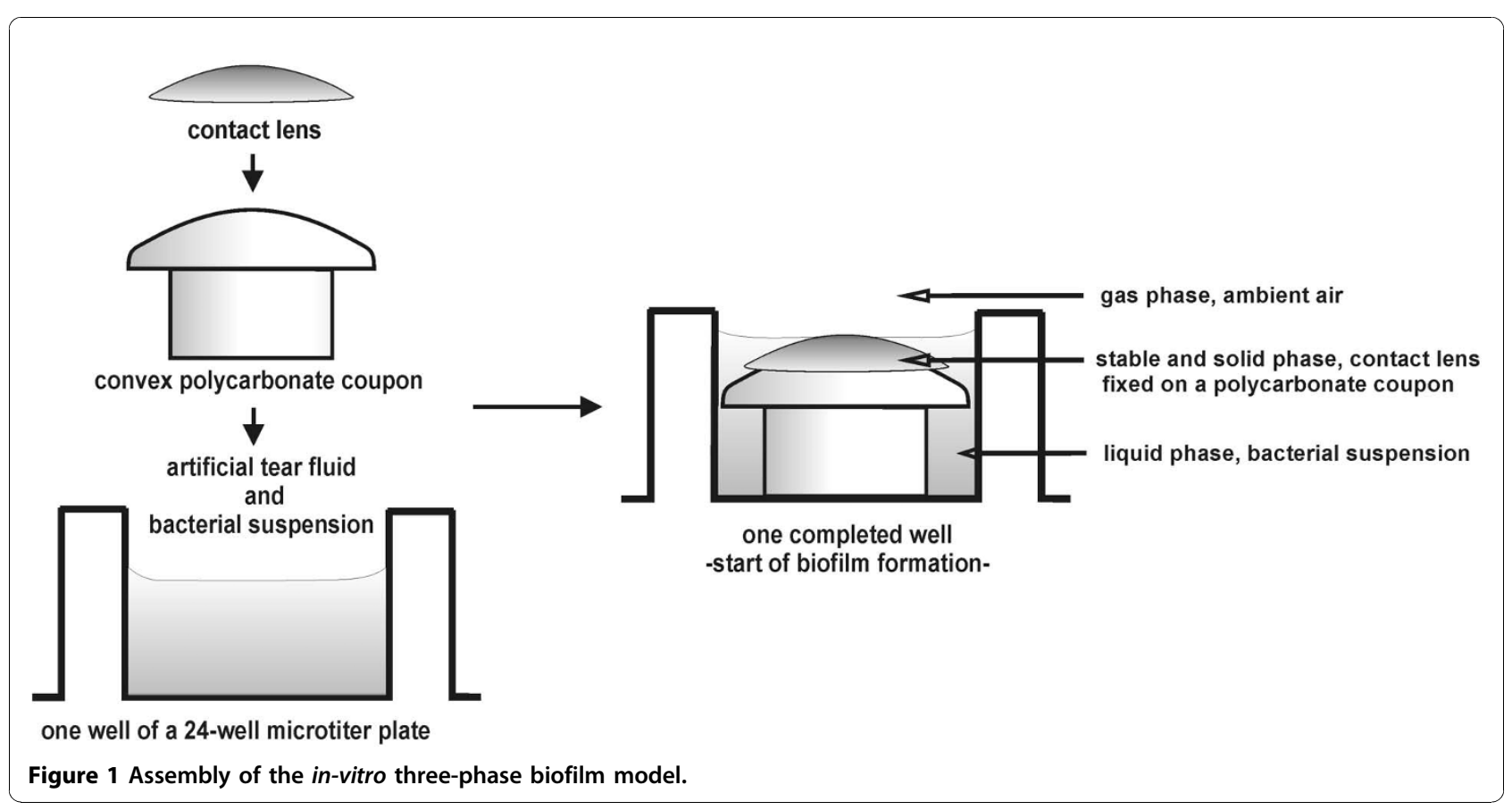


carefully removed at the indicated times and gently washed in PBS. To harvest the biofilm from the CL surface, vortex agitation in the presence of glass beads $(2 \mathrm{~mm} \varnothing)$ was performed for $2 \mathrm{~min}$. This regimen has been found to effectively remove adhered bacteria without significantly reducing their viability. After removal, viable cells were quantified using colony counting in log serial dilutions of the homogenate. Two aliquots of each dilution were plated on trypticase soy agar plates and incubated for $24 \mathrm{~h}$ at $37^{\circ} \mathrm{C}$. This adherence assay was performed in quadruplicate for each incubation time and for each CL material. The results were reported in log transformations of the CFUs per surface area of the $\mathrm{CL}\left(\log \left[\mathrm{CFU} / \mathrm{cm}^{2}\right]\right)$.

\section{Confocal laser scanning microscopy}

Biofilm samples were visualised using a ZEISS LSM 510 META confocal laser scanning microscope (CLSM510, Zeiss, Jena, Germany). Microscopic observations were performed using a Plan-Neofluar $40 \times$ oil immersion objective with a numerical aperture of 1.3. Confocal images, unless noted otherwise, represent $1-\mu \mathrm{m}$-thick confocal slices of the specimen. Non-confocal, transmitted light images were generated by the longest excitation wavelength of the respective multi-track channel combination and a transmitted-light detector below the specimen/focal plane.

Following incubation, the washed CL samples were transferred to a 24-well microtiter plate and incubated immediately with one of four dyes (Table 2). CTC was used for determining the respiratory activity and viability of the bacterial cells. The reduction of CTC by the respiratory electron transport chain of viable bacterial cells leads to insoluble, fluorescent formazan crystals (CTF) [34]. Concanavalin (Con) A (a lectin) conjugated with the fluorescent substance Alexa Fluor 488 was used to visualise polysaccharides: when Con A Alexa Fluor 488 is intercalated into the glucose and mannose residues of polysaccharides, green fluorescence signals are emitted [35]. Even though Con A intercalates mainly into reducing sugars, Wingender et al. $[35,36]$ have observed that it is also suitable for the visualisation of alginate within the EPS of the strain $P$. aeruginosa SG81. Acridine orange is a nucleic-acid selective fluorescent dye and interacts with DNA and RNA by intercalation and electrostatic attractions, respectively [37]. DAPI exhibits a particular affinity to double-stranded DNA and is considerably more intensively fluorescent in the intercalation state [38]. An advantage of DAPI is that it can be used concurrently with CTC, due to their different emission ranges, whereas acridine orange exhibits nearly the same emission range as CTC (Table 2).

After incubation, an effective washing and preparation method was necessary, because dyes stain not only into the biofilm matrix but also into the $\mathrm{CL}$ material, which may produce strong background fluorescence. Therefore, the samples were rinsed at least five times with PBS to reduce background fluorescence. After staining and washing, the CL samples were placed onto glass slides, embedded in 10 $\mu \mathrm{L}$ Mowiol 4-88 (Polysciences Inc., Warrington, USA) and covered with a cover slip for observation by CLSM.

\section{Scanning electron microscopy (SEM)}

$P$. aeruginosa adhesion to CLs was also observed by SEM (DSM-940A, Zeiss, Oberkochen, Germany) at various magnifications $(100 \times, 500 \times, 2000 \times, 5000 \times)$. All buffer solutions were passed through $0.2 \mu \mathrm{m}$ filters to eliminate background particles. The CL samples were fixed in HEPES buffer (10 mM, pH 7.4) containing $\mathrm{NaN}_{3}(50 \mathrm{mM}), 3 \%$ glutaraldehyde, and 4\% paraformaldehyde for $1 \mathrm{~h}$ at room temperature and then overnight at $4^{\circ} \mathrm{C}$.

Further treatment was carried out using two different methods. They were: i. critical point drying, which consisted of $2 \%$ tannic acid for $1 \mathrm{~h}, 1 \%$ osmium tetroxide for $2 \mathrm{~h}, 1 \%$ thiocarbohydrazide for $30 \mathrm{~min}, 1 \%$ osmium tetroxide overnight, and $2 \%$ uranyl acetate for $2 \mathrm{~h}$, with washing steps in between. The samples were then dehydrated by immersion in increasing concentrations of ethanol $(10-100 \%)$ and dried in a critical point drier using amylacetate and liquid $\mathrm{CO}_{2}$; ii. sodium hydroxide

Table 2 Characteristics of the fluorescent dyes used in confocal laser scanning microscopy

\begin{tabular}{|c|c|c|c|c|c|}
\hline $\begin{array}{l}\text { Fluorescent } \\
\text { substance }\end{array}$ & Manufacturer & $\begin{array}{l}\text { Excitation } \\
\text { wavelength (Laser) } \\
\text { in [nm] }\end{array}$ & $\begin{array}{l}\text { Emission } \\
\text { range in } \\
\text { [nm] }\end{array}$ & $\begin{array}{l}\text { Concentration/ } \\
\text { incubation time/ } \\
\text { temperature }\end{array}$ & $\begin{array}{l}\text { Fluorescence } \\
\text { of }\end{array}$ \\
\hline $\begin{array}{l}\text { Acridine } \\
\text { orange }\end{array}$ & $\begin{array}{l}\text { Acridine orange - zinc chloride, Applichem GmbH, } \\
\text { Darmstadt; Germany }\end{array}$ & Argon 458 & $\begin{array}{l}505-550 \mathrm{BP} \\
592-753 \mathrm{BP}\end{array}$ & $\begin{array}{l}200 \mu \mathrm{g} / \mathrm{mL} ; \\
2-5 \mathrm{~min} ; \mathrm{RT}\end{array}$ & nucleic acids \\
\hline DAPI & $\begin{array}{l}\text { Dapi Biochemica, Applichem GmbH, Darmstadt; } \\
\text { Germany }\end{array}$ & Diode 405 & $420-480$ BP & $\begin{array}{l}20 \mu \mathrm{g} / \mathrm{mL} ; \\
30 \mathrm{~min} ; \mathrm{RT}\end{array}$ & nucleic acids \\
\hline $\begin{array}{l}\text { ConA-Alexa } \\
\text { Fluor } 488\end{array}$ & $\begin{array}{l}\text { Concanavalin A - Alexa Fluor } 488 \text { conjugated, } \\
\text { Invitrogen Molecular Probes, Eugene, USA }\end{array}$ & Argon 488 & 505-530 BP & $\begin{array}{l}10 \mu \mathrm{g} / \mathrm{mL} ; \\
30 \mathrm{~min} ; \mathrm{RT}\end{array}$ & polysaccharides \\
\hline CTC & $\begin{array}{l}\text { CTC (5-Cyano-2,3-di-4-tolyl-tetraolium chloride), } \\
\text { Polysciences Inc.; Warrington, USA }\end{array}$ & Diode 561 & $575 \mathrm{LP}$ & $\begin{array}{l}1.25 \mathrm{mg} / \mathrm{mL} ; \\
3 \mathrm{~h} ; \mathrm{RT}\end{array}$ & redox activity \\
\hline
\end{tabular}


drying: osmium tetroxide vapor for 3 days; drying over sodium hydroxide disks for 3 weeks at $-20^{\circ} \mathrm{C}$. All samples were mounted onto aluminum stubs and sputtercoated with gold for observation using SEM.

\section{Statistical analyses}

Statistical analyses were performed using analysis of variance (ANOVA) to determine the main effects of CL material and incubation time, and the interaction effect on biofilm growth in $\left(\log \left[\mathrm{CFU} / \mathrm{cm}^{2}\right]\right)$. Additionally, ANOVA was performed with Tukey's HSD post-hoc test to compare the viable bacterial cell counts in log $\left[\mathrm{CFU} / \mathrm{cm}^{2}\right]$. Two distinct comparisons were made: i. differences between the viable cell counts at different incubation times $(24,48$ and $72 \mathrm{~h}$ ) independent of the $\mathrm{CL}$ materials and separately for each CL material; ii. differences between the viable cell counts on various $C L$ materials independent of the incubation times and separately for each incubation time. $\mathrm{P} \leq 0.05$ was considered statistically significant.

\section{Results}

\section{Pseudomonas aeruginosa biofilm growth on various contact lens materials}

To evaluate biofilm formation in the novel in-vitro biofilm model (Figure 1), the accumulation of viable bacterial cells over time was measured on four CLs using quantitative culturing (Figure 2). For comparison and for statistical analysis, variation between the CL materials in terms of viable cell counts in $\log \left[\mathrm{CFU} / \mathrm{cm}^{2}\right]$ after 24, 48 and 72 h growth are represented separately in Figure 3. Analysis of variance showed that biofilm growth was significantly affected primarily by the incubation time, and secondarily by the CL material. The interaction effect of time and material had a comparatively minor effect (Table 3 ).

Although viable cell numbers significantly increased over time, independent of the CL material (Table 4), distinct patterns of growth for each CL material were observed. Biofilm formation on Etafilcon A (FDA Group 4) showed a latent phase between $2 \mathrm{~h}$ and $4 \mathrm{~h}$, followed by continuous, rapid accumulation within $24 \mathrm{~h}$, a latent phase on the second day, followed by a significant growth phase on the third day. Biofilm formation on Omafilcon A (FDA Group 2) progressed through an early latent phase in the first $4 \mathrm{~h}$, followed by rapid growth to a comparatively high level of adhered cells within $24 \mathrm{~h}$, and last by an intermediate phase between $24 \mathrm{~h}$ and $72 \mathrm{~h}$ with significantly decelerated growth. In contrast, biofilm formation on Comfilcon A (FDA Group 1) was characterised by a decrease in growth between $2 \mathrm{~h}$ and $4 \mathrm{~h}$, followed by the lowest increase in growth on the first day and significant rapid growth on the second day. After 2 days, a stationary phase for biofilm formation was reached on Comfilcon A. Lotrafilcon B (FDA Group 1) also showed a decrease in growth between $2 \mathrm{~h}$ and $4 \mathrm{~h}$, but yielded the highest initial number of adhered viable cells within $24 \mathrm{~h}$ growth, followed by a significant continuous increase in biofilm growth up to $48 \mathrm{~h}$; a stationary phase after 2 days was also attained.

A comparison of the viable cell counts associated with the test CL materials after $24 \mathrm{~h}$ showed no significant difference between the different CL materials (Table 5), due to the broad variance of the data. After $72 \mathrm{~h}$ however, variance was minimal and as a result, significant differences were observed between the viable cell counts of the various CLs. Accordingly, significantly more

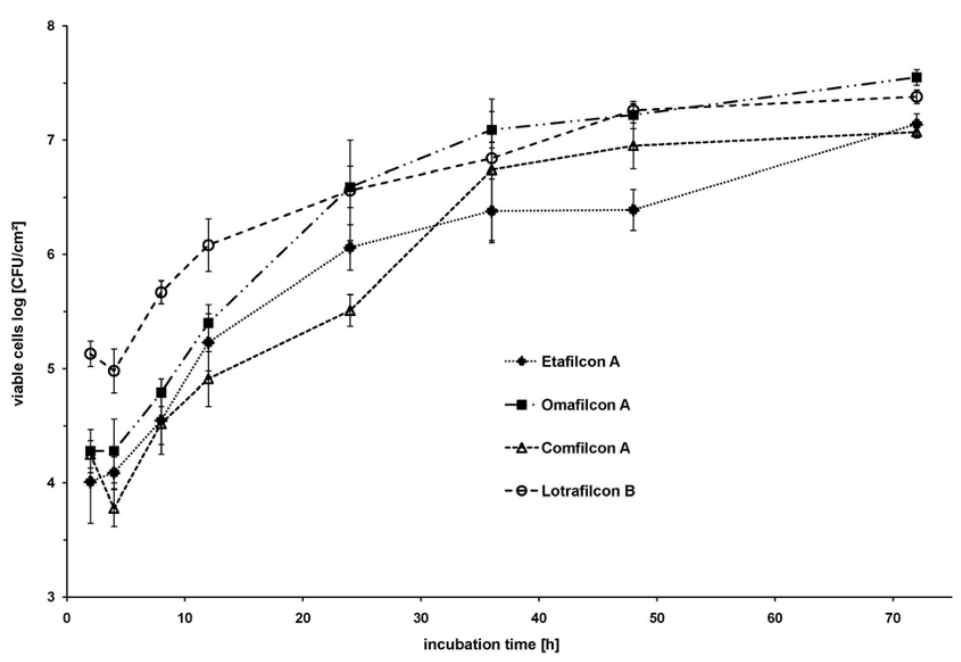

Figure 2 Biofilm growth dynamics on contact lens materials. Curves represent the means of data in log [CFU/ $\left.\mathrm{cm}^{2}\right]$; all test were performed in quadruplicate ( \pm standard deviation). 
Table 3 Results of analysis of variance: main effects of contact lens material and incubation time and the interaction effect on bacterial adherence of $P$. aeruginosa SG81 over time

\begin{tabular}{llllll}
\hline Source & Sum of Squares & DF & Mean Square & F Value & Sig. \\
\hline Contact lens material & 3.276 & 3 & 1.092 & 28.266 & $<0.001$ \\
Incubation time & 9.293 & 2 & 4.646 & 120.278 & $<0.001$ \\
Contact lens material * Incubation time & 1.569 & 6 & 0.261 & 6.769 & $<0.001$ \\
Error & 1.198 & 31 & 0.039 & & \\
Corrected total & 15.292 & 42 & & & \\
\hline
\end{tabular}

viable $P$. aeruginosa SG81 cells grew in $72 \mathrm{~h}$ (Figure 3) on Omafilcon A $\left(7.55 \pm 0.07 \log \left[\mathrm{CFU} / \mathrm{cm}^{2}\right]\right)$ and Lotrafilcon $\mathrm{B}\left(7.38 \pm 0.06 \mathrm{log}\left[\mathrm{CFU} / \mathrm{cm}^{2}\right]\right)$ than on Etafilcon A $\left(7.14 \pm 0.09 \log \left[\mathrm{CFU} / \mathrm{cm}^{2}\right]\right)$ and Comfilcon A (7.07 \pm $\left.0.05 \log \left[\mathrm{CFU} / \mathrm{cm}^{2}\right]\right)$. Although there were differences in kinetics, biofilms grown for $72 \mathrm{~h}$ were used in qualitative experiments because variance in biofilm formation was minimised at this point of time, and biofilms had reached a stationary phase on most of the CL materials.

\section{Characterisation of biofilms on contact lenses using CLSM and SEM}

To characterise the predominant biofilm structures on various CL materials (Figure 4), biofilms were stained with CTC for observation of the viable bacterial cells. The biofilms of the various CL materials often showed a heterogeneous EPS structure, visible as ConA Alexa Fluor 488, green stained fluorescent, cloud-like regions. Bacterial adhesion densities on Etafilcon A and Comfilcon A were obviously lower than on Omafilcon A and Lotrafilcon $\mathrm{B}$, which correlated with the findings of the viable cell count analysis.

Among the observed, predominant biofilm morphologies, various structures were characterised, independent of the CL material. For example, Figure 5 depicts a heterogeneous biofilm stained with DAPI and CTC for examining the proportion of total and viable bacterial cells. A comparison of DAPI and CTC fluorescent regions showed that most of the cells were viable. Additionally, $P$. aeruginosa SG81 biofilms were found to occur either in a homogeneous, thin, dispersed structure (Figure 6) or in a more heterogeneous, compact form

Table 4 Significance of the differences between the viable cell counts of $P$. aeruginosa SG81 at different incubation times

\begin{tabular}{lccc}
\hline Contact lens material & \multicolumn{3}{c}{ Comparison of the incubation times } \\
& $\mathbf{2 4} \mathbf{~ h - 4 8 ~} \mathbf{~}$ & $\mathbf{2 4} \mathbf{~ h} \mathbf{- 7 2} \mathbf{~ h}$ & $\mathbf{4 8} \mathbf{~} \mathbf{- ~ 7 2 ~} \mathbf{~}$ \\
\hline Independent & $<0.001$ & $<0.001$ & $<0.001$ \\
Etafilcon A & 0.084 & $<0.001$ & 0.003 \\
Omafilcon A & 0.004 & $<0.001$ & 0.020 \\
Comfilcon A & $<0.001$ & $<0.001$ & 0.435 \\
Lotrafilcon B & 0.041 & 0.020 & 0.868 \\
\hline
\end{tabular}

Tukey's HSD Post-hoc test. $\mathrm{P} \leq 0.05$ was considered statistically significant.
(Figure 5). Whilst both structures were found on every $\mathrm{CL}$, the heterogeneous form was predominant. Furthermore, the architecture of the biofilms formed at the periphery of the CLs differed from those at the centre. Specifically, the central air-exposed region was characterised by crystalline and granular structures (Figure 7) which were often surrounded by agglomerations of bacterial cells. Other biofilm structures, such as the formation of fibres between crystals, were only rarely found. Bacterial cells embedded along the fibres were apparent following acridine orange staining.

Various biofilm structures were also observed by SEM (Figure 8). SEM micrographs of samples prepared according to the method of dehydration by immersion in increasing concentrations of ethanol followed by critical point drying depicted networks of EPS formations with fibres and clumps. Ethanol preparation led to denaturation of proteins within the EPS, resulting in a clear visualisation of exposed bacterial cells (Figure 8A-C).

Table 5 Significance of the differences between the viable cell counts of $P$. aeruginosa SG81 on different CL materials

\begin{tabular}{|c|c|c|c|}
\hline \multirow[t]{2}{*}{ Incubation time } & \multicolumn{3}{|c|}{ Contact lens material } \\
\hline & 2 & 3 & 4 \\
\hline \multicolumn{4}{|l|}{ Independent } \\
\hline 1 & $<0.001$ & 0.987 & $<0.001$ \\
\hline 2 & - & $<0.001$ & 0.980 \\
\hline 3 & - & - & $<0.001$ \\
\hline \multicolumn{4}{|l|}{$24 \mathrm{~h}$} \\
\hline 1 & 0.070 & 0.057 & 0.093 \\
\hline 2 & - & 0.001 & 0.998 \\
\hline 3 & - & - & 0.001 \\
\hline \multicolumn{4}{|l|}{$48 \mathrm{~h}$} \\
\hline 1 & 0.001 & 0.008 & 0.001 \\
\hline 2 & - & 0.515 & 0.743 \\
\hline 3 & - & - & 0.154 \\
\hline \multicolumn{4}{|l|}{$72 \mathrm{~h}$} \\
\hline 1 & $<0.001$ & 0.601 & 0.006 \\
\hline 2 & - & $<0.001$ & 0.033 \\
\hline 3 & - & - & 0.001 \\
\hline
\end{tabular}




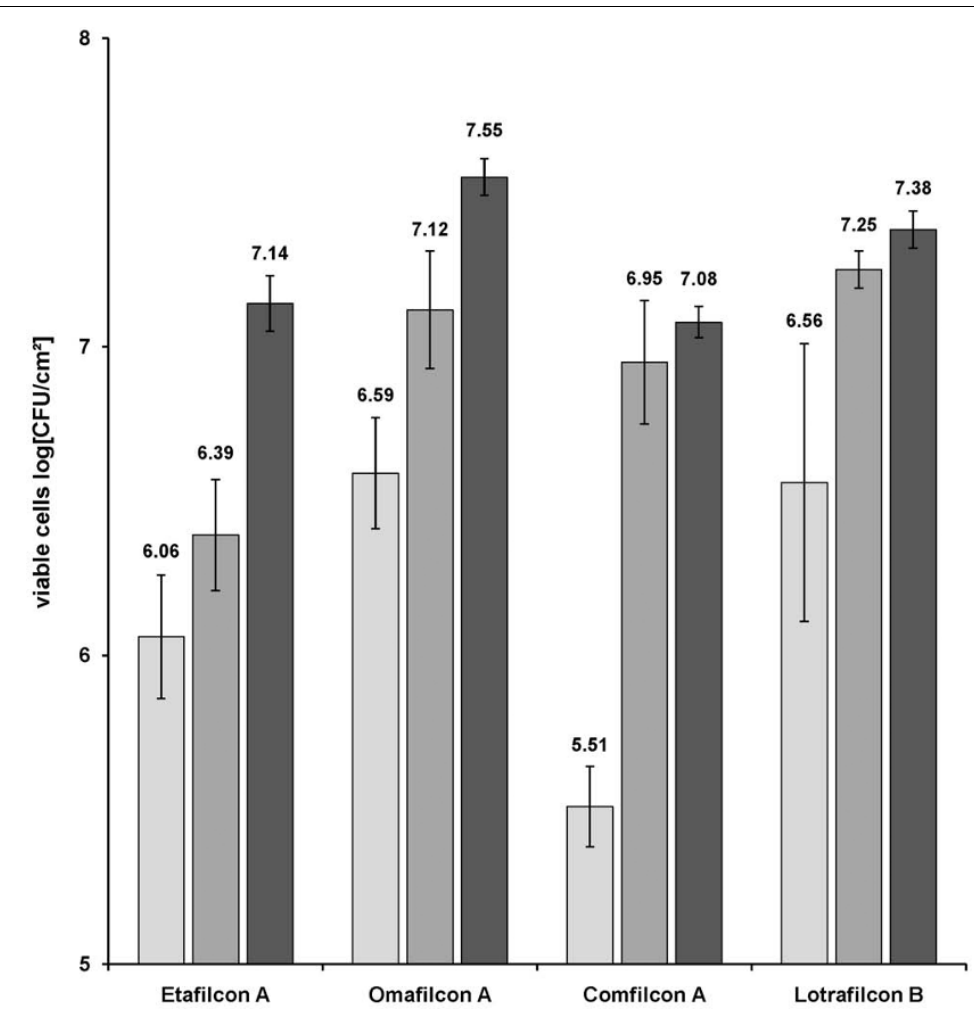

Figure 3 P. aeruginosa biofilm cell counts for various contact lens materials after $\mathbf{2 4 ,} \mathbf{4 8}$ and $\mathbf{7 2} \mathbf{h}$ of growth. Results are the means of data performed in quadruplicate ( \pm standard deviation) in $\log \left[\mathrm{CFU} / \mathrm{cm}^{2}\right]$ at the different incubation times: $24 \mathrm{~h}$ (light grey), $48 \mathrm{~h}$ (middle grey) and $72 \mathrm{~h}$ (dark grey).

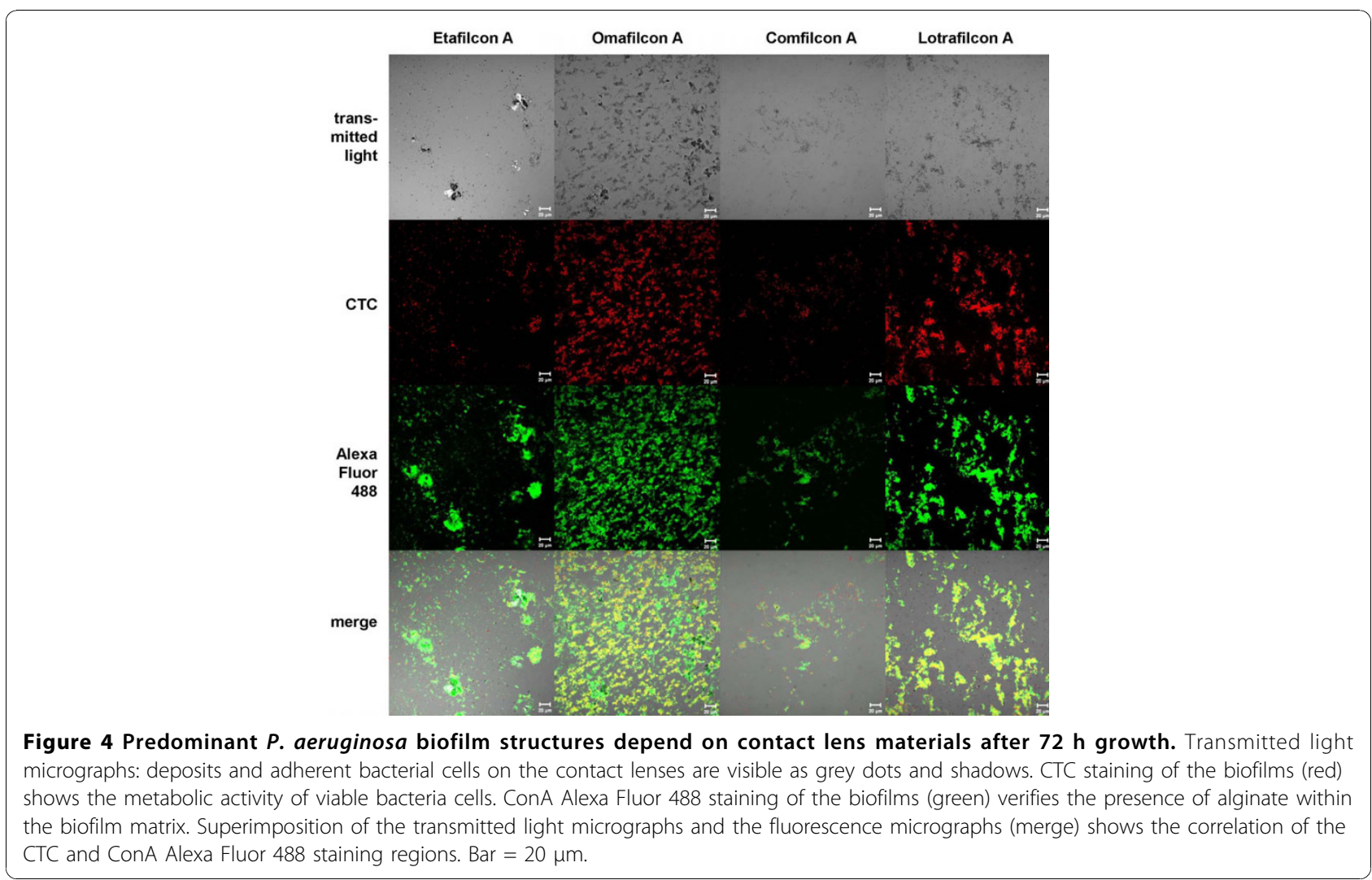



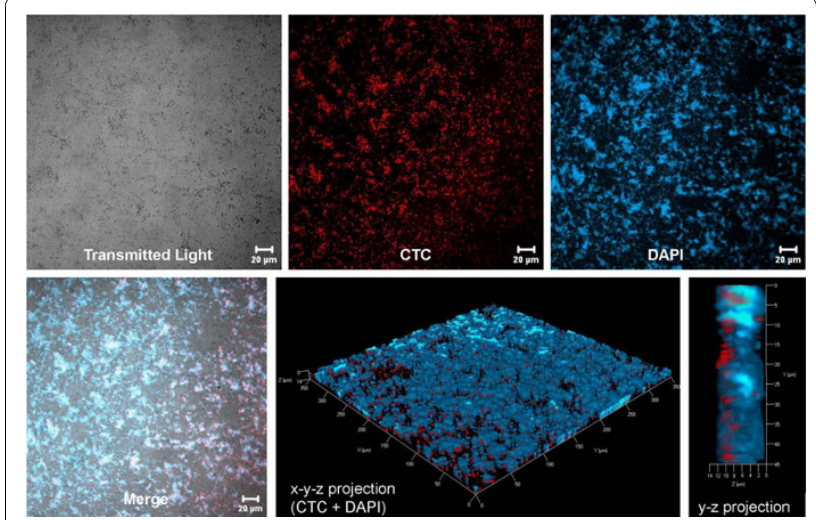

Figure 5 Cells of $P$. aeruginosa SG81 adhere in patches to Lotrafilcon B after $\mathbf{7 2} \mathbf{~ h}$ incubation. Transmitted light micrograph: deposits and adherent bacterial cells on the contact lens are visible as grey dots and shadows. DAPI staining of the biofilm (blue) shows all adherent bacterial cells (viable and dead). CTC staining of the biofilm (red) shows the metabolic activity of the viable bacterial cells. Superimposition of the transmitted light micrograph and the fluorescence micrographs (merge) shows the correlation of the CTC and DAPI stained regions. The three-dimensional representation gives an illustration of the spatial structure and the thickness of the biofilm matrix $(\sim 12 \mu \mathrm{m})$. Bar $=20 \mu \mathrm{m}$.

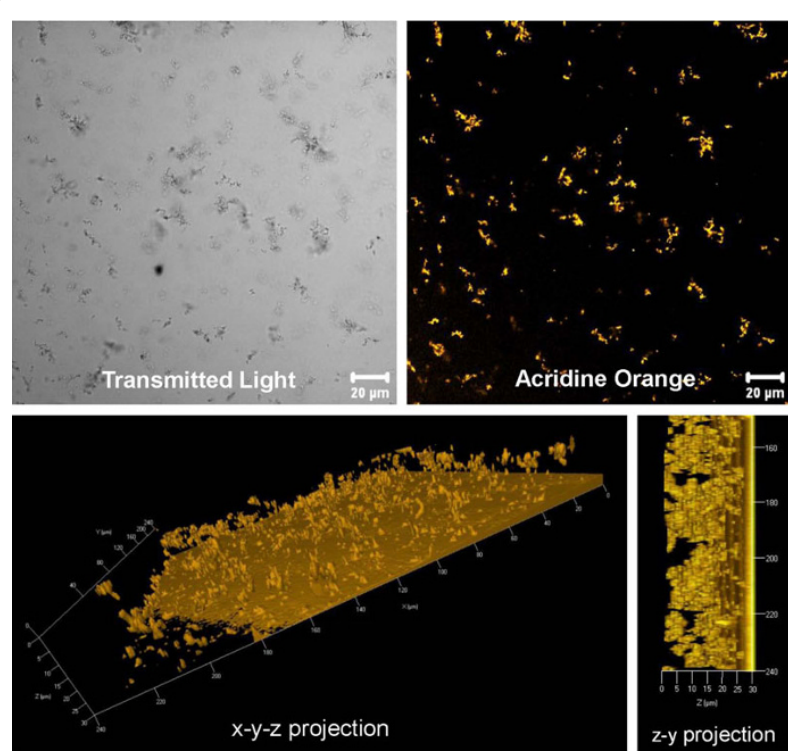

Figure 6 Small colonies of $P$. aeruginosa cells are dispersed homogeneously and thinly throughout the biofilm matrix on Etafilcon $\mathbf{A}$ after $\mathbf{7 2} \mathbf{~} \mathbf{~ g r o w t h}$. The non-confocal transmitted light micrograph and the acridine orange stained micrograph are $x-y$ projections of a slice of the $z$-stack $(z=12 \mu \mathrm{m})$ of the biofilm matrix. Bacterial cells were stained with the dye acridine orange to observe the total amount of bacterial cells (viable and dead). The three-dimensional representation of the biofilm stained with acridine orange illustrates the distribution of the bacterial cells throughout the biofilm matrix and the thickness of the biofilm matrix $(\sim 30 \mu \mathrm{m})$. Furthermore, the fluorescent dye acridine orange intercalates not only into nucleic acids but also into the contact lens hydrogel polymer matrix.

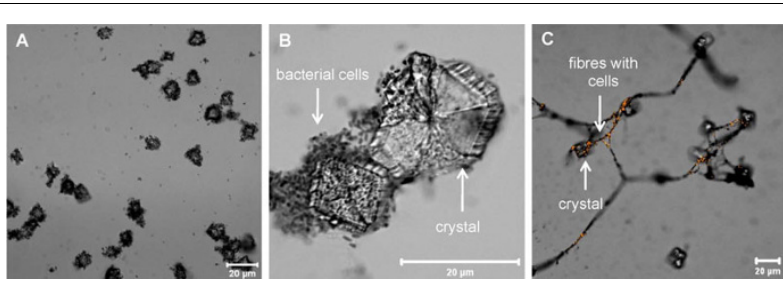

Figure 7 Various, rarely observed biofilm structures such as crystals, granular materials and fibres on the air-exposed contact lens surface after $\mathbf{7 2} \mathbf{~ h}$ growth. Extensive agglomerations of bacterial cells were found to adhere to the surface of crystals and granular materials. Crystals and granular materials were also associated with the formation of fibres. Acridine orange staining of the fibres verifies the presence of bacterial cells throughout the fibres. Bar $=20 \mu \mathrm{m}$.

When SEM samples were prepared according to the method of prolonged sodium hydroxide drying without denaturation, a thick, mature biofilm consisting of clumps, mushroom-like formations and networks of EPS and bacterial cells was observed (Figures 8D-F). Other structures such as a conditioning film covering the CL surface or a cover layer overlapping the biofilm matrix were also observed (Figures $8 \mathrm{D}$ and $8 \mathrm{~F}$ ).

\section{Discussion}

Several biofilm models have previously been used to investigate bacterial adhesion upon CLs, mainly in planktonic suspensions in microtiter plates $[13,19,28-32]$ or by suspending CLs in culture vessels $[8,16,17,24,26$, 27,39-41]. Another approach, which provides a continuous

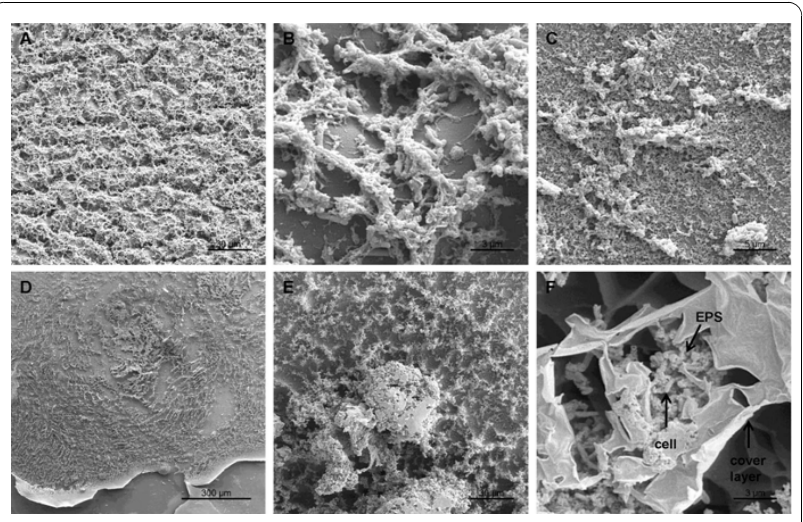

Figure 8 Observation of various biofilm structures using SEM techniques after $\mathbf{7 2} \mathbf{~} \mathbf{~ i n c u b a t i o n . ~ B i o f i l m s ~ i n ~ A - C ~ w e r e ~ p r e p a r e d ~}$ using the SEM method with critical point drying. Biofilms in D-F were prepared using the SEM method with prolonged sodium hydroxide drying. Etafilcon A: A (500x), B (5000x), D (100x); Omafilcon A: C (2000x), E (500x), F (5000x). Different structural formations appear to cover the contact lens surface: extensive networks consisting of EPS and bacterial cells, mushroom-like structure, clumps and cover layers overlap compact, thick agglomerations of cells which are embedded in a network of EPS. 
nutrient supply, involves the location of CL materials into flow cells $[20-23,42]$. These biofilm models are predominantly two-phase systems, since they provide a solid:liquid interface and furthermore, in the absence of a support system, the convex surface curvature of the CL is likely to vary significantly with loss of the normally convex surface tension, for example within flow cells and other model systems due to fluid dynamic forces. Although these in-vitro biofilm models are useful for obtaining information about the characteristics of bacterial adhesion on CL surfaces, it is suggested that the elaborations presented in the current study provide a greater degree of realism. These are $i$. the use of a mucoid, environmental bacterial strain, ii. the use of a complex artificial tear fluid, iii. the incorporation of a convex contact surface to stabilise the convex shape of the $\mathrm{CL}$, in a manner analogous to that of the human cornea, iv. exposure of the solid substratum (i.e. the CL) to both, liquid and air, phases and v. the simulation of eyelid movements.

Given that suboptimal use and care of CLs is known to be common [43-45] among CL wearers, the model described in the current study was designed to produce mature, recalcitrant biofilms which reproduce the morphology and importantly, the resistance properties of real-life ocular biofilms that can occur following incorrect wearing schedules, and ineffective CL care. $P$. aeruginosa SG81 is a stable, alginate-producing strain that forms strongly mucoid colonies on standard media agar $[35,46]$ and has been previously validated as model organism for investigation of in-vitro biofilm formations $[35,36,47,48]$. With this strain, morphologically mature biofilms were generated on every test CL material.

With respect to growth media, the majority of previous studies have reported the use of nutritionally inert PBS suspensions [13,23-28,32,39,49] or have used simple proteins such as lysozyme [17] or albumin [31] in aqueous solution. More complex artificial tear fluids have also been developed $[8,16,19,30]$ consisting of for example, a mixture of turkey egg white lysozyme, immunoglobulin A from human colostrum, bovine lactoferrin, serum albumin and mucin [16]. Since natural tear fluid and human blood serum show marked similarities in $\mathrm{pH}$ value, osmolarity, ionic strength, and protein composition [6,50-52], the artificial tear fluid used in the current investigation offers a relatively high degree of realism. Because of their similarities, human blood serum has been previously used clinically as a replacement for human tear fluid [52-54]. Although human blood serum represents a useful analogue of human tear fluid, serum has a higher protein concentration, lower quantities of antimicrobial substances, and lacks tear-specific proteins. In the current investigation therefore, the protein concentration of serum was reduced to a physiologically relevant value by diluting 1:5 with the ocular irrigation solution $\mathrm{BSS}^{\circledast}$ and the tear-specific protein lysozyme was added at a physiological concentration. The serum used was pooled and aliquotted from 50 different patient samples and thus avoids in-vivo variation between single serum samples.

To prevent the deformation of the flexible CL caused by floating loosely in a suspension that presumably is a common feature of previously reported models, supportive coupons incorporating convex contact surfaces were machined from polycarbonate. The resulting support of the CLs resulted in a stable, solid surface with a high surface tension incident to the convex shape of the CL. Additionally, intermittent contact with air for the central section of the CL was achieved by the use of continuous rotational mixing, combined with adjustment of the volume of artificial tear fluid so that the top of the CL surface was in contact with air in a manner similar to that which occurs in-vivo through the movement of the eyelid (Figure 1). Continuous agitation also effectively avoided dehydration of CLs. The effect of the third phase, forming a solid:air interface, and eyelid movements on bacterial adhesion to CLs has infrequently been reported in literature $[21,24,30,55]$. Vermeltfoort et al. [21] passed air bubbles over the CL to mimic the natural shear action of blinking of the eyelid. Borazjani et al. [24] proposed that the effect of tear flow and the shear force of blinking may limit bacterial development on worn CLs.

In the current study, viable bacterial numbers on the silicone CLs decreased within the first few hours, an observation that contrasts with some previous studies $[19,25,26,33,56]$, which have generally reported a continuous increase of initial bacterial adherence. One possible explanation for this is that, in contrast to many previous studies, the artificial tear fluid used here contained antimicrobial components such as lysozyme, which may lead to an initial viable cell reduction before physiological adaptation of the bacteria could occur. Furthermore, in the current investigation, biofilms grew significantly in the first $48 \mathrm{~h}$, and maturation and decelerated growth were not observed until then. In contrast, Stapleton et al. [26] reported maximal adherence after $45 \mathrm{~min}$, followed by a decrease in growth and Andrews et al. [57] reported maximum adhesion following $4 \mathrm{~h}$ incubation. The results in the current study suggest that the conditions of the novel three-phase biofilm model may lead to slower growth over time, and the compounds of the artificial tear fluid may limit doubling times to rates more congruent with those expected in-vivo.

With respect to visualisation of CL biofilms, the formation of diverse, heterogeneous $P$. aeruginosa biofilms has been commonly reported. Stapleton et al. [26] for example, observed a thin sheet of fixed material on the 
surface of the CL that was associated with "headed-up" granular material adjacent to adhered bacteria. Other studies have noted large bacterial cell colonies on $\mathrm{CL}$ surfaces $[22,24]$ or bacterial cells adhered in aggregates or clumps and stuck to EPS on albumin-coated CLs [31]. However, biofilms observed in the current study were generally more compact and extensive than in previous studies and were associated with large quantities of EPS.

Importantly, biofilm structures generated in the current model exhibit several similarities to those reported in an in-vivo study by McLaughlin-Borlace et al. [58] where biofilms developed various structures including clumps and networks of bacterial cells, embedded in EPS, together with thick, multilayered biofilms. The formation of a conditioning film or cover layer structures on the CL surfaces, as observed in this investigation has also been often reported in in-vivo studies [59-62]. Other biofilm structures, such as crystal formations, have also been observed in-vivo [63] and in-vitro [64,65]. Such similarities suggest that the three-phase biofilm model represents an improvement on two-phase systems.

\section{Conclusion}

For standardised, realistic biofilm tests, an effective invitro model is required which closely mimics the in-vivo conditions of CL wear. The current study has demonstrated that growth of $P$. aeruginosa SG81 in the threephase in-vitro biofilm model can simulate worst-case CL use conditions. Whilst a variety of biofilm morphological structures was observed, a compact and heterogeneous biofilm morphology predominated. Further investigations are needed to determine whether the biofilms can be standardised in order to utilise the model for the evaluation of the anti-biofilm efficacy of CL care solutions.

\section{Acknowledgements \\ The authors would like to thank CooperVision GmbH (Eppertshausen, Germany), Fielmann AG (Hamburg, Germany) and Fielmann Akademie (Plön, Germany) for providing CL samples; Prof. Dr. Hans-Curt Flemming (Biofilm Centre; University of Duisburg-Essen, Duisburg, Germany) for his help and support in this project and the Transfusion Medicine Center of the University of Greifswald for providing human blood serum samples. This research was conducted with the financial support of ANOVIS Biotech GmbH (Ahlen, Germany) and Lapis Lazuli International NV (Almere, Netherlands). The assistance of the SEM core facility and CLSM core facility at the University of Greifswald, Germany, is gratefully acknowledged. BG and MF were funded by the German Ministry for Science and Research (BMBF) within the program "Entrepreneurial Regions: Competence Centers" under code ZIK011. $\mathrm{RM}$ and $\mathrm{NOH}$ are funded within the framework of the multi-disciplinary research cooperative Campus PlasmaMed, a grant funded by the German Ministry of Education and Research (BMBF, grant no, 13N9779).}

\section{Author details}

${ }^{1}$ Department of Hygiene and Environmental Medicine, Ernst Moritz Arndt University Greifswald, Greifswald, Germany. ${ }^{2}$ School of Pharmacy and Pharmaceutical Sciences, The University of Manchester, Manchester, UK.
${ }^{3}$ Competence Center for Functional Genomics, Ernst Moritz Arndt University Greifswald, Greifswald, Germany. ${ }^{4}$ Department of Microbiology, Ernst Moritz Arndt University Greifswald, Greifswald, Germany. ${ }^{5}$ Institute of Community Medicine, Ernst Moritz Arndt University Greifswald, Greifswald, Germany.

\section{Authors' contributions}

$\mathrm{CR}, \mathrm{NOH}$, and AK designed the study. AK coordinated the study. CR and RM performed the adhesion assays. CLSM was performed by CR, BG, and RM. RS performed SEM. TK and CR was responsible for statistical analysis and interpretation of the data. CR and AJM wrote the manuscript and RM, BG, $M F, R S, T K, N O H$ and AK were involved in drafting the manuscript and revising it critically for important intellectual content. All authors have read and approved the final manuscript.

Received: 23 October 2009 Accepted: 9 November 2010

Published: 9 November 2010

\section{References}

1. Pleyer U, Behrens-Baumann W: [Bacterial keratitis. Current diagnostic aspects]. Ophthalmologe 2007, 104(1):9-14.

2. Bourcier T, Thomas F, Borderie V, Chaumeil C, Laroche L: Bacterial keratitis: predisposing factors, clinical and microbiological review of 300 cases. $\mathrm{Br}$ J Ophthalmol 2003, 87(7):834-838.

3. Erie JC, Nevitt MP, Hodge DO, Ballard DJ: Incidence of ulcerative keratitis in a defined population from 1950 through 1988. Arch Ophthalmol 1993, 111(12):1665-1671

4. Patel $\mathrm{A}$, Hammersmith $\mathrm{K}$ : Contact lens-related microbial keratitis: recent outbreaks. Curr Opin Ophthalmol 2008, 19(4):302-306.

5. Donlan RM: Biofilms: microbial life on surfaces. Emerg Infect Dis 2002, 8(9):881-890.

6. Sariri R, Ghafoori $\mathrm{H}$ : Tear proteins in health, disease, and contact lens wear. Biochemistry (Mosc) 2008, 73(4):381-392.

7. Bialasiewicz AA: [Infection immunology in silicone hydrogel contact lenses for continuous wear-a review]. Klin Monatsbl Augenheilkd 2003, 220(7):453-458.

8. Willcox MD, Harmis N, Cowell, Williams T, Holden : Bacterial interactions with contact lenses; effects of lens material, lens wear and microbial physiology. Biomaterials 2001, 22(24):3235-3247.

9. Micallef C, Cuschieri P, Bonnici MR: Contamination of contact-lens-related sources with Pseudomonas aeruginosa. Ophthalmologica 2000, 214(5):324-331.

10. Lipener C, Nagoya FR, Zamboni FJ, Lewinski R, Kwitko S, Uras R: Bacterial contamination in soft contact lens wearers. Clao J 1995, 21(2):122-124.

11. Brewitt H: [Contact lenses. Infections and hygiene]. Ophthalmologe 1997, 94(5):311-316.

12. Berke A, Bluemle S: Sterilisation-Desinfektion-Konservierung. In Kontaktlinsen Hygiene. Edited by: Berke A, Bluemle S. Pforzheim: Bode GmbH 1996:121-135.

13. Simmons PA, Tomlinson A, Seal DV: The role of Pseudomonas aeruginosa biofilm in the attachment of Acanthamoeba to four types of hydrogel contact lens materials. Optom Vis Sci 1998, 75(12):860-866.

14. Galentine PG, Cohen EJ, Laibson PR, Adams CP, Michaud R, Arentsen JJ: Corneal ulcers associated with contact lens wear. Arch Ophthalmol 1984, 102(6):891-894.

15. Stern GA, Zam ZS: The effect of enzymatic contact lens cleaning on adherence of Pseudomonas aeruginosa to soft contact lenses. Ophthalmology 1987, 94(2):115-119.

16. Miller MJ, Wilson LA, Ahearn DG: Effects of protein, mucin, and human tears on adherence of Pseudomonas aeruginosa to hydrophilic contact lenses. J Clin Microbiol 1988, 26(3):513-517.

17. Zhang S, Borazjani RN, Salamone JC, Ahearn DG, Crow SA Jr, Pierce GE: In vitro deposition of lysozyme on etafilcon $A$ and balafilcon $A$ hydrogel contact lenses: effects on adhesion and survival of Pseudomonas aeruginosa and Staphylococcus aureus. Cont Lens Anterior Eye 2005, 28(3):113-119.

18. Boles SF, Refojo MF, Leong FL: Attachment of Pseudomonas to humanworn, disposable etafilcon A contact lenses. Cornea 1992, 11(1):47-52.

19. Rediske AM, Koenig AL, Barekzi N, Ameen LC, Slunt JB, Grainger DW: Polyclonal human antibodies reduce bacterial attachment to soft contact lens and corneal cell surfaces. Biomaterials 2002, 23(23):4565-4572. 
20. Bruinsma GM, van der Mei $H C$, Busscher $H J$ : Bacterial adhesion to surface hydrophilic and hydrophobic contact lenses. Biomaterials 2001, 22(24):3217-3224.

21. Vermeltfoort PB, Rustema-Abbing $M$, de Vries J, Bruinsma GM, Busscher $H J$ van der Linden ML, Hooymans JM, van der Mei HC: Influence of day and night wear on surface properties of silicone hydrogel contact lenses and bacterial adhesion. Cornea 2006, 25(5):516-523.

22. Cook AD, Sagers RD, Pitt WG: Bacterial adhesion to protein-coated hydrogels. J Biomater Appl 1993, 8(1):72-89.

23. Cook AD, Sagers RD, Pitt WG: Bacterial adhesion to poly(HEMA)-based hydrogels. J Biomed Mater Res 1993, 27(1):119-126.

24. Borazjani RN, Levy B, Ahearn DG: Relative primary adhesion of Pseudomonas aeruginosa, Serratia marcescens and Staphylococcus aureus to HEMA-type contact lenses and an extended wear silicone hydrogel contact lens of high oxygen permeability. Cont Lens Anterior Eye 2004, 27(1):3-8

25. Miller MJ, Ahearn DG: Adherence of Pseudomonas aeruginosa to hydrophilic contact lenses and other substrata. J Clin Microbiol 1987, 25(8):1392-1397.

26. Stapleton F, Dart JK, Matheson M, Woodward EG: Bacterial adherence and glycocalyx formation on unworn hydrogel lenses. Journal of the British Contact Lens Association 1993, 16(3):113-117.

27. Dang YN, Rao A, Kastl PR, Blake RC Jr, Schurr MJ, Blake DA: Quantifying Pseudomonas aeruginosa adhesion to contact lenses. Eye Contact Lens 2003, 29(2):65-68.

28. George M, Ahearn D, Pierce G, Gabriel M: Interactions of Pseudomonas aeruginosa and Staphylococcus epidermidis in adhesion to a hydrogel. Eye Contact Lens 2003, 29(1 Suppl):S105-109, discussion S115-108, S192-104.

29. Kodjikian L, Casoli-Bergeron E, Malet F, Janin-Manificat H, Freney J, Burillon C, Colin J, Steghens JP: Bacterial adhesion to conventional hydrogel and new silicone-hydrogel contact lens materials. Graefes Arch Clin Exp Ophthalmol 2008, 246(2):267-273.

30. Henriques M, Sousa C, Lira M, Elisabete M, Oliveira R, Oliveira R, Azeredo J: Adhesion of Pseudomonas aeruginosa and Staphylococcus epidermidis to silicone-hydrogel contact lenses. Optom Vis Sci 2005, 82(6):446-450.

31. Taylor RL, Willcox MD, Williams TJ, Verran J: Modulation of bacterial adhesion to hydrogel contact lenses by albumin. Optom Vis Sci 1998, 75(1):23-29.

32. Imamura Y, Chandra J, Mukherjee PK, Lattif AA, Szczotka-Flynn LB, Pearlman E, Lass JH, O'Donnell K, Ghannoum MA: Fusarium and Candida albicans biofilms on soft contact lenses: model development, influence of lens type, and susceptibility to lens care solutions. Antimicrob Agents Chemother 2008, 52(1):171-182.

33. Szczotka-Flynn LB, Imamura Y, Chandra J, Yu C, Mukherjee PK, Pearlman E, Ghannoum MA: Increased resistance of contact lens-related bacterial biofilms to antimicrobial activity of soft contact lens care solutions. Cornea 2009, 28(8):918-926.

34. Schaule G, Flemming HC, Ridgway HF: Use of 5-cyano-2,3-ditolyl tetrazolium chloride for quantifying planktonic and sessile respiring bacteria in drinking water. Appl Environ Microbiol 1993, 59(11):3850-3857.

35. Wingender J, Strathmann M, Rode A, Leis A, Flemming HC: Isolation and biochemical characterization of extracellular polymeric substances from Pseudomonas aeruginosa. Methods Enzymol 2001, 336:302-314.

36. Strathmann M, Wingender J, Flemming HC: Application of fluorescently labelled lectins for the visualization and biochemical characterization of polysaccharides in biofilms of Pseudomonas aeruginosa. J Microbiol Methods 2002, 50(3):237-248.

37. Darzynkiewicz Z: Differential staining of DNA and RNA in intact cells and isolated cell nuclei with acridine orange. Methods Cell Biol 1990, 33:285-298.

38. Kubista M, Akerman B, Norden B: Characterization of interaction between DNA and 4,6-diamidino-2-phenylindole by optical spectroscopy. Biochemistry 1987, 26(14):4545-4553.
39. Garcia-Saenz MC, Arias-Puente A, Fresnadillo-Martinez MJ, Paredes-Garcia B Adherence of two strains of Staphylococcus epidermidis to contact lenses. Cornea 2002, 21(5):511-515.

40. Arciola CR, Maltarello MC, Cenni E, Pizzoferrato A: Disposable contact lenses and bacterial adhesion. In vitro comparison between ionic/highwater-content and non-ionic/low-water-content lenses. Biomaterials 1995, 16(9):685-690.

41. Miller MJ, Wilson LA, Ahearn DG: Adherence of Pseudomonas aeruginosa to rigid gas-permeable contact lenses. Arch Ophthalmol 1991, 109(10):1447-1448

42. Santos L, Rodrigues D, Lira M, Oliveira ME, Oliveira R, Vilar EY, Azeredo J: The influence of surface treatment on hydrophobicity, protein adsorption and microbial colonisation of silicone hydrogel contact lenses. Cont Lens Anterior Eye 2007, 30(3):183-188.

43. Yung MS, Boost M, Cho P, Yap M: Microbial contamination of contact lenses and lens care accessories of soft contact lens wearers (university students) in Hong Kong. Ophthalmic Physiol Opt 2007, 27(1):11-21.

44. Whiting MA, Raynor MK, Morgan PB, Galloway P, Tole DM, Tullo A: Continuous wear silicone hydrogel contact lenses and microbial keratitis. Eye 2004, 18(9):935-937.

45. Cardona G, Saona-Santos CL: Corneal thinning associated with recurrent microbial keratitis resulting from 7-day extended wear of low Dk hydrogel contact lenses: a case report. Cont Lens Anterior Eye 2010, 33(1):30-32.

46. Grobe S, Wingender J, Truper HG: Characterization of mucoid Pseudomonas aeruginosa strains isolated from technical water systems. J Appl Bacteriol 1995, 79(1):94-102.

47. Strathmann M: Visualisierung und Charakterisierung von extrazellulären polymeren Substanzen in Biofilmen. Osnabrück: Der Andere Verlag; 2003, 27-67.

48. Strathmann M, Griebe T, Flemming HC: Artificial biofilm model-a useful tool for biofilm research. Appl Microbiol Biotechnol 2000, 54(2):231-237.

49. Santos L, Rodrigues D, Lira M, Oliveira Real ME, Oliveira R, Vilar EY, Azeredo J: The influence of lens material and lens wear on the removal and viability of Staphylococcus epidermidis. Cont Lens Anterior Eye 2008, 31(3):126-130.

50. Farris RL: Tear analysis in contact lens wearers. Trans Am Ophthalmol Soc 1985, 83:501-545.

51. Van Haeringen NJ: Clinical biochemistry of tears. Surv Ophthalmol 1981 26(2):84-96

52. Geerling G, Maclennan S, Hartwig D: Autologous serum eye drops for ocular surface disorders. Br J Ophthalmol 2004, 88(11):1467-1474.

53. Geerling G, Unterlauft JD, Kasper K, Schrader S, Opitz A, Hartwig D: [Autologous serum and alternative blood products for the treatment of ocular surface disorders]. Ophthalmologe 2008, 105(7):623-631.

54. Kasper K, Godenschweger L, Hartwig D, Unterlauft JD, Seitz B, Geerling G: [On the use of autologous serum eyedrops in Germany: results of a survey among members of the Cornea Section of the German Ophthalmological Society (DOG)]. Ophthalmologe 2008, 105(7):644-649.

55. John G, Shields M, Austin F, McGinnis S: Increased Pseudomonas aeruginosa adhesion following air drying of etafilcon A soft contact lenses. Clao J 1998, 24(4):236-238.

56. Duran JA, Refojo MF, Gipson IK, Kenyon KR: Pseudomonas attachment to new hydrogel contact lenses. Arch Ophthalmol 1987, 105(1):106-109.

57. Andrews CS, Denyer SP, Hall B, Hanlon GW, Lloyd AW: A comparison of the use of an ATP-based bioluminescent assay and image analysis for the assessment of bacterial adhesion to standard HEMA and biomimetic soft contact lenses. Biomaterials 2001, 22(24):3225-3233.

58. McLaughlin-Borlace L, Stapleton F, Matheson M, Dart JK: Bacterial biofilm on contact lenses and lens storage cases in wearers with microbial keratitis. J Appl Microbiol 1998, 84(5):827-838.

59. Klein AE: Detection of mucin deposits on hydrogel contact lenses: evaluation of staining procedures and clinical significance. Optom Vis Sci 1989, 66(1):56-60. 
60. Kaplan EN, Gundel RE: Anterior hydrogel lens deposits: polished vs. unpolished surfaces. Optom Vis Sci 1996, 73(3):201-203.

61. Brennan NA, Coles ML: Deposits and Symptomatology with Soft Contact Lens Wear. Iclc 2000, 27:75-100.

62. Bilbaut T, Gachon AM, Dastugue B: Deposits on soft contact lenses. Electrophoresis and scanning electron microscopic examinations. Exp Eye Res 1986, 43(2):153-165.

63. Merindano MD, Canals M, Saona C, Potau J, Costa J: Observation of deposits on disposable contact lenses by bio-, light and scanning electron microscopy. Cont Lens Anterior Eye 1998, 21(2):55-59.

64. Mirejovsky D, Patel AS, Rodriguez DD, Hunt TJ: Lipid adsorption onto hydrogel contact lens materials. Advantages of Nile red over oil red $\mathrm{O}$ in visualization of lipids. Optom Vis Sci 1991, 68(11):858-864.

65. Levy B: Calcium deposits on glyceryl methyl methacrylate and hydroxyethyl methacrylate contact lenses. Am J Optom Physiol Opt 1984, 61(9):605-607.

doi:10.1186/1471-2180-10-282

Cite this article as: Rändler et al: A three-phase in-vitro system for studying Pseudomonas aeruginosa adhesion and biofilm formation upon hydrogel contact lenses. BMC Microbiology 2010 10:282.

\section{Submit your next manuscript to BioMed Central} and take full advantage of:

- Convenient online submission

- Thorough peer review

- No space constraints or color figure charges

- Immediate publication on acceptance

- Inclusion in PubMed, CAS, Scopus and Google Scholar

- Research which is freely available for redistribution

Submit your manuscript at www.biomedcentral.com/submit
Ciomed Central 